\title{
Povaha směnečného vyplňovacího práva
}

\section{The Character of the Right to Complete a Blank Bill of Exchange}

\section{Zuzana Dvořáková*}

\begin{abstract}
Abstrakt
Ačkoli je smènečné vyplňovaci právo jednim zpojmových znakủ blankosmènky, nebyla jeho povaha doposud uspokojivě objasnèna. Objevují se názory, keteré smènečné vyplñovaci právo považuji za zmocnèní, za právo utváreci nebo právo sui generis. Závèr o povaze smènečnébo vyplñovacíbo práva by mèl být pritom stěžejni pro navazujici otázky týkajici se jeho promlčeni či prevoditelnosti. Cílem článku je zaràdit smènečné vyplňovaci právo do systému práv a charakterizovat jeho podstatu, a to i ve srovnánís názory zabraničnich autori.

\section{Klíčová slova}

Blankosmènka; smènečné vyplňovací právo; utvárecí právo; żmocnèní; podminka.

Abstract

Although the right to complete a blank bill of exchange is one of the conceptual features of the blank bill, its nature has not been satisfactorily explained. There are opinions that the bill-of-exchange right considers to be empowerment, the right of formation or the sui generis right. The conclusion on the nature of the bill-of-exchange right should be central to the subsequent questions about its limitation or transferability. The aim of the article is to include the bill-of-exchange right in the system of rights and characterize its substance, even in comparison with the opinions of foreign authors.
\end{abstract}

\section{Keywords}

Blank Bill of Exchange; Right to Complete a Blank Bill of Exchange; Right of Formation; Empowerment; Condition.

\section{Úvod}

Jako blankosměnka bývá označována listina, která obsahuje podpis potencionálního směnečného dlužníka a která je určena za směnku, s tím, že dále zpravidla obsahuje více či méně podstatných či nepodstatných náležitostí směnky. Na rozdíl od směnek, které jsou pro absenci podstatných náležitostí neplatné, nebot' jejich neúplnost je důsledkem omylu nebo neznalosti účastníků, je absence některých náležitostí na blankosměnce záměrná. Společně s jejím vydáním totiž výstavce uděluje směnečné vyplňovací právo, kterým opravňuje nabyvatele blankosměnky k jejímu pozdějšímu doplnění, a tedy i k její přeměně na směnku úplnou. Sjednání směnečného vyplňovacího práva je tedy jedním z pojmových znaků blankosměnky. Jeho udělení odlišuje blankosměnku, tedy směnku při vydání záměrně neúplnou, od jiných neúplných směnek, u nichž absence podstatných

* Mgr. Zuzana Dvořáková, doktorandka, Katedra obchodního práva, Právnická fakulta, Masarykova univerzita, Brno / Ph.D. student, Department of Commercial Law, Faculty of Law, Masaryk University, Brno, Czech Republic / E-mail: 371539@mail.muni.cz 
náležitostí nebyla záměrem účastníků směnečných vztahů a která tudíž způsobuje jejich neplatnost. Směnečné vyplňovací právo opravňuje svého nositele k pozdějším zásahům do textu blankosměnky.

I přes nesporný význam vyplňovacího práva $\mathrm{v}$ životě blankosměnky nebyla doposud uspokojivě objasněna jeho podstata. V novodobé teorii lze pozorovat dva základní názorové proudy. První, s nímž se lze setkat převážně ve švýcarské odborné literatuře, považuje směnečné vyplňovací právo za zmocnění, druhý, který se objevuje v německé doktríně, jej charakterizuje jako utvářecí právo. Dále bývá v souvislosti se směnečným vyplňovacím právem zmiňován podmíněný směnečný závazek, tedy snad další, třetí kategorie. Většina autorů však současně s argumenty pro zařazení vyplňovacího práva do jedné z těchto kategorií předkládá i protiargumenty nebo upozorňuje na sporné otázky začlenění tohoto práva. Někteří naopak s ohledem na charakter vyplňovacího práva rezignují na jeho zařazení do některé z výše uvedených kategorií, např. J. Kotásek označuje směnečné vyplňovací právo jako právo sui generis. ${ }^{1}$

I přes rozdílnost názorů na povahu tohoto práva však panuje shoda na jeho základních rysech. Směnečné vyplňovací právo bývá charakterizováno jako převoditelné, zděditelné, neodvolatelné majetkové právo, jehož realizací dochází k přeměně neúplné směnky (blankosměnky) na směnku úplnou. Zdá se tedy, že i přes různé názory na povahu směnečného vyplňovacího práva panuje jednota $\mathrm{v}$ tom, jaké jsou jeho znaky. Nejistota ohledně charakteru vyplňovacího práva není tedy překážkou poměrně jasné představy o jeho vlastnostech, které se s různými názory na povahu směnečného vyplňovacího práva zásadně nemění. Při hledání podstaty vyplňovacího práva se lze proto o tyto jeho charakteristické znaky oprít. Stejně tak se lze opř́t o účinky, které jeho realizace vyvolává.

I když se zdá být otázka povahy vyplňovacího práva otázkou ryze teoretickou, má praktické dopady, kvưli nimž má smysl se jí zabývat. Mezi ně lze zařadit převod blankosměnky a směnečného vyplňovacího práva, jeho promlčení, vliv ztráty a zničení blankosměnky na existenci vyplňovacího práva, př́ípadnou možnost výkonu tohoto práva $\mathrm{v}$ př́padě umoření blankosměnky či odůvodnění námitkového postavení výstavce blankosměnky. Cílem textu je objasnit podstatu směnečného vyplňovacího práva v návaznosti na již známé instituty. Za tímto účelem text shrnuje některé doposud vyslovené názory na jeho povahu a podrobněji se jimi zabývá. Hledá odpověd’ na otázku, zda je možné vyplňovací právo podřadit pod některou nám známou kategorii práv, nebo zda se jedná o právo sui generis. Spíše než na otázku čím směnečné vyplňovací právo je, však odpovídá na otázku, čím směnečné vyplňovací právo není.

Úvodní kapitola obsahuje stručné zařazení vyplňovacího práva do systému práv. Následuje popis vlastností směnečného vyplňovacího práva, na nichž panuje shoda,

1 KOTÁSEK, Josef. Zákon směnečný a šekový. Komentár. 2. akt. vyd. Praha: Wolters Kluwer Česká republika, 2017, s. 109. ISBN 978-80-7552-544-4. 
a z nichž lze vyjít při hledání podstaty směnečného vyplňovacího práva. Další pasáže shrnují názory na povahu směnečného vyplňovacího práva vyslovené českými i zahraničními autory. Poté se text zaměřuje na jednotlivé názory o povaze směnečného vyplňovacího práva. Poslední část je věnována shrnutí.

Na úvod je třeba uvést několik slov k výstavci blankosměnky a nabyvateli blankosměnky (resp. oprávněnému z blankosměnky, oprávněnému ze směnečného vyplňovacího práva). Osobou, která blankosměnku vydává a která uděluje směnečné vyplňovací právo, nemusí být pouze výstavce vlastní nebo cizí směnky, může jím být i akceptant směnky cizí (blankoakcept) nebo aval. Označení výstavce blankosměnky budu nadále používat v jeho širším slova smyslu, tedy ve významu osoby, která vydala směnečný blanket a udělila směnečné vyplňovací právo bez ohledu na to, zda po doplnění blankosměnky bude v postavení výstavce, avala či akceptanta. Pokud jde o nabyvatele blankosměnky, mohou nastat situace, kdy nabyvatel blankosměnky a tedy i oprávněný ze směnečného vyplňovacího práva bude odlišný od remitenta blankosměnky. V tomto příspěvku tyto situace záměrně pro jisté zjednodušení opomenu a oprávněným z blankosměnky budu rozumět vždy remitenta blankosměnky, který se stal nabyvatelem blanketu a oprávněným ze směnečného vyplňovacího práva. Oprávněného z blankosměnky budu označovat i jako nabyvatele blanketu.

\section{Zařazení směnečného vyplňovacího práva do systému práv}

Na úvod následujících úvah o povaze směnečného vyplňovacího práva je třeba toto právo zařadit do systému práv, tedy posoudit, zda se jedná o právo absolutní či relativní, věcné či závazkové a konečně, zda se jedná o právo majetkové nebo osobní či osobnostní. ${ }^{2}$

V. Knapp rozlišuje absolutní a relativní práva podle toho, vůči komu tato práva působí. Zatímco relativní práva „(...) puisobi v relaci k určitému subjektu povinnosti“، absolutní práva působí vưči neurčitému počtu subjektů povinnosti. Zatímco povinností odpovídající relativnímu právu může být jakékoli chování, povinností odpovídající absolutnímu právu je jen povinnost zdržet se rušení práva. ${ }^{3}$ Pokud subjektivnímu právu odpovídá povinnost konkrétního subjektu, jedná se o právo relativní, pokud oprávnění působí vưči všem, jde o právo absolutní (např. vlastníkovým subjektivním právům odpovídá povinnost všech ostatních jej ve výkonu práva nerušit). ${ }^{4}$ Relativní právo tedy působí „(...) jen mezi koonkerétními, individualizovanými stranami právníbo pomèru (... ". 5

2 „Pre jeho náležitú analýzu nie je zrejme nevyhnutné definitivne ho začlenit’ do oblasti obligačného či vecnébo práva, pripadne ho stotožnit's právnym postavenim účastnika niektorej z typových zmlúv súkromnébo práva. "SEDLAČKO, František. Blankozmenka a právo na jej vyplnenie (prvá část). Bulletin slovenskej advokacie, Bratislava: Slovenská advokátská komora, 2011, roč. XVII, č. 7-8, s. 14.

3 KNAPP, Viktor. Teorie práva. Praha: C. H. Beck, 1995, s. 196. ISBN 80-7179-028-1.

4 FIALA, Josef, Milan KINDL a kol. Občanské právo bmotné. 2. vyd. Plzeň: Aleš Čeněk, 2009, s. 179. ISBN 978-80-7380-228-8.

5 SPÁČIL, Jiří. Kapitola 1. Věcná práva a absolutní majetková práva. In: SPÁČIL, Jiří a kol. Věcná práva. Praha: C. H. Beck, 2018, s. 3. ISBN 978-80-7400-711-8. 
Protože směnečnému vyplňovacímu právu neodpovídá povinnost blíže neurčeného počtu subjektů zdržet se rušení tohoto práva, ale toto právo působí pouze mezi konkrétními stranami právního poměru, nelze směnečné vyplňovací právo zařadit mezi práva absolutní. Směnečné vyplňovací právo působí mezi tím, kdo jej vykonává, tedy oprávněným z blankosměnky, a mezi výstavcem blankosměnky. Proto je třeba zařadit směnečné vyplňovací právo mezi práva relativní.

Dále lze rozlišovat mezi právy věcnými a závazkovými. Pro věcná práva je charakteristická vázanost subjektivních práv a povinností na předmět právního vztahu, u závazkového vztahu závisí práva a povinnosti na jejich účastnících. „Vêcná práva jsou absolutní majetková práva týkajici se věci, zpravidla hmotné, poskytuji prómé právni panstvi nad věcí, jeji primmé ovládáni; oprávnèný realizuje své právo k véci prímo, neni prìtom v zásadě (...) vázán na součnnost jiných osob. V šichni ostatni maji povinnost oprávnèného pri výkonu práva nerusìt. " Věcná práva lze charakterizovat jako práva absolutní, tedy práva, která působí vưči všem ostatním subjektům; povinnost má zpravidla negativní povahu, omezuje se tedy na nekonání, konkrétně na nekonání toho, čím by se zasahovalo do výkonu věcného práva. ${ }^{7}$ Navíc v případě práv věcných se uplatňuje princip numerus clausus. Počet věcných práv je tedy v konkrétním právním řádu uzavřeným počtem. V případě vlastnictví blankosměnky jako listiny, tedy věci, bude mít její vlastník všechna vlastnická práva, v tomto rozsahu má tedy práva věcná. Aby se cenný papír stal majetkem nabyvatele, je ostatně jedna z podmínek vzniku budoucí směnky. ${ }^{8}$ Současně však nabyvatel (oprávněný z blankosměnky) při vydání blankosměnky (vedle nabytí vlastnického práva $\mathrm{k}$ listině) vstupuje s jejím výstavcem do závazkového vztahu, přičemž obsahem tohoto vztahu jsou vzájemná práva a povinnosti, přičemž jedním z těchto práv je i směnečné vyplňovací právo. Směnečnému vyplňovacímu právu neodpovídá povinnost blíže neurčené skupiny subjektů, ale naopak povinnost konkrétní osoby, výstavce blankosměnky, strpět realizaci vyplňovacího práva a př́ipadný vznik směnečného závazku. Směnečné vyplňovací právo je tedy právem relativním. Z. Kovařík dovozuje, že směnečné vyplňovací právo má dvojí povahu - věcnou a smluvní, přičemž věcná povaha směnečného vyplňovacího práva

6 SPÁČIL, Jiří. Kapitola 1. Věcná práva a absolutní majetková práva. In: SPÁČIL, Jiří a kol. Věcná práva. Praha: C. H. Beck, 2018, s. 9. ISBN 978-80-7400-711-8.

7 FIALA, Josef, Milan KINDL a kol. Občanské právo bmotné. 2. vyd. Plzeň: Aleš Čeněk, 2009, s. 190. ISBN 978-80-7380-228-8.

8 O majetku - nikoli o vlastnictví - se v tomto ustanovení normuje z toho důvodu, že k vydání cenného papíru může dojít i v př́padě, že náležitosti postupu při vydání cenného papíru nebyly dodrženy nebo že se cenný papír nestal stanoveným způsobem vlastnictvím prvního nabyvatele (ustanovení nebere zřetel na zlou či dobrou víru prvního nabyvatele). Jde o dưležité právní pravidlo sledující ochranu dobrověrných dalších osob. Důvodová zpráva k zákonu č. 89/2012 Sb., občanský zákoník. In: Sněmovní tisky. Parlament Ceské republiky, Poslanecké sněmovna [online]. 2011, VI. volební období, 2011, Sněmovní tisk 362/0, část č. 1/2 [cit. 17. 4. 2019]. Dostupné z: http://www.psp.cz/sqw/text/tiskt. sqw? $\mathrm{O}=6$ \& $\mathrm{CT}=362 \& \mathrm{CT} 1=0$ 
umožňuje do blankosměnky doplnit cokoli. ${ }^{9}$ Mám za to, že právo vyplnit do blankosměnky cokoli (a tedy i právo blankosměnku jakkoli poškrtat nebo i zničit) neplyne z věcné povahy vyplňovacího práva, ale ze skutečnosti, že přri vydání blankosměnky se její nabyvatel (oprávněný z blankosměnky) stává jejím majitelem. I majitel směnky může do směnky z titulu vlastnického práva $\mathrm{k}$ listině dopisovat cokoli, tyto jeho zásahy do směnky však mohou být ve smyslu čl. I \ 69 ZSŠ považovány za neoprávněnou změnu textu směnky a směnečného dlužníka tedy nebudou zavazovat (neoprávněnou změnou textu směnku bude i situace, kdy do neplatné směnky bude doplněn údaj, díky čemuž bude odstraněn důvod neplatnosti, provede-li toto doplnění věrititel, aniž by byl k takovému doplnění oprávněn). Právo doplnit do blankosměnky cokoli tedy není projevem věcné stránky směnečného vyplňovacího práva, ale skutečnosti, že při vydání blankosměnky se oprávněný ze směnečného vyplňovacího práva zpravidla stává vlastníkem blankosměnky a právo doplnit cokoli do této listiny je tedy projevem jeho vlastnického práva. Věcnou povahu směnečného vyplňovacího práva dovodil i J. Spišiak, a to s odůvodněním, že směnečné vyplňovací právo nepatří do skupiny práv obligačních, tudíž musí patřit do druhé skupiny práv - práv věcných. Opírá se přitom o závěr, že obligační povaha vyplňovacího práva neumožňuje uspokojivě řešit právní problémy související s blankosměnkou, což naopak věcná povaha tohoto práva umožňuje. Dále argumentuje, že vyplňovací právo není právem na pohledávku, ale oprávněním vytvořit instrument, na základě kterého je možné pohledávku uplatnit. Vyplňovací právo je vnitřní vlastností blankosměnky, je výkonem oprávnění, které se pojí k vlastnictví směnky. ${ }^{10}$

Směnečné vyplňovací právo je dále možné charakterizovat jako právo majetkové. „Majetkovým právem je takové právo, jehož predmètem je majetek; tím je soubrn všeho, co osobě patrǐ" (I $495 \mathrm{ObčZ}$ ), tedy, soubrn vécí, práv a jiných majetkových hodnot náležejicich téžze osobè... Majetkem se tedy rozumi soubrn aktivnich hodnotorých položek náležejici určité osobé (...)؛ " 11 Vyplňovací právo není spojeno s osobností člověka ani různými stránkami této osobnosti. Nelze je proto zařadit mezi práva osobní. Naopak směnečné vyplňovací právo spíše než s osobou, které bylo uděleno, je spojeno s blankosměnkou, k níž bylo uděleno. Pokud by se navíc jednalo o právo osobní, nebyl by možný jeho převod. Jak bude uvedeno níže, panuje všeobecná shoda na tom, že směnečné vyplňovací právo je zděditelné i převoditelné, přičemž oba tyto charakteristické rysy pramení právě z majetkové podstaty vyplňovacího práva.

Směnečné vyplňovací právo je tedy relativním závazkovým majetkovým právem.

9 KOVAŘÍK, Zdeněk. Smènka a šek v České republice. 6. vyd. Praha: C. H. Beck, 2011, s. 118. ISBN 978-7400-402-5.

10 SPIŠIAK, Ján. Blankoz̧menka. Bratislava: Právnická fakulta univerzity Komenského v Bratislavě, 1938, s. 66.

11 SPÁČIL, Jiří. Kapitola 1. Věcná práva a absolutní majetková práva. In: SPÁČIL, Jiří a kol. Věcná práva. Praha: C. H. Beck, 2018, s. 5. ISBN 978-80-7400-711-8. 


\section{Základní charakteristické rysy směnečného vyplňovacího práva}

Bez ohledu na podstatu vyplňovacího práva panuje shoda na jeho základních charakteristických znacích. Následující rádky se proto budou zabývat těmi charakteristickými znaky blankosměnky, resp. směnečného vyplňovacího práva, na kterých panuje obecná shoda.

Předně je třeba uvést, že směnečné vyplňovací právo má smluvní povahu. Vzniká na základě dohody uzavřené mezi výstavcem blankosměnky a jejím nabyvatelem. Ačkoli může být tato dohoda uzavřena zcela bezformálně, tedy i konkludentně, nelze její existenci ničím nahradit. ${ }^{12} \mathrm{Na}$ tomto závěru prritom nic nemění ani skutečnost, že v některých prrípadech se její uzavření s ohledem na skutkové okolnosti předpokládá. ${ }^{13}$ Argumentovat lze čl. I \ 10 ZSŠ, který upravuje námitku protismluvního doplnění, a kterou výslovně vztahuje k rozporu vyplnění blankosměnky a dohody, kterou právo doplnit blankosměnku bylo uděleno. ${ }^{14}$

V návaznosti na závěry přijaté německou doktrínou bývá směnečné právo charakterizováno jako právo samostatné, neodvolatelné, děditelné a převoditelné. ${ }^{15}$

Neodvolatelnost vyplňovacího práva je odůvodňována funkcí, kterou blankosměnka plní v hospodářském životě. Blankosměnka může plnit svoji funkci pouze tehdy, pokud nabyvatel blanketu nebo jeho právní nástupce mưže blankosměnku doplnit a vytvořit tak platnou směnku, aniž by se ho dotkly jakékoli možné neznámé okolnosti v osobě výstavce blankosměnky. ${ }^{16}$ Pokud by měl výstavce blankosměnky možnost udělené vyplňovací právo kdykoli odvolat, ztratila by směnka $v$ hospodářském životě svůj smysl, nebot' nabyvatel blankosměnky ani jeho nástupce by nikdy neměli jistotu, zda vyplňovací právo existuje či nikoli, a z blankosměnky by se tedy stala bezcenná listina. ${ }^{17}$

12 Rozsudek Vrchního soudu v Olomouci ze dne 20. 1. 2004, sp. zn. 9 Cmo 536/2003.

13 „Jestliže výstavce a smènéný rukojmi podepsali blankosmènku, ve keteré nebyly vyplnèny údaje smènečné sumy, data splatnosti a data vystavení, pričemž pisemná dohoda o vyplňovacím právu výslovně upravovala pouze podminky pro vyplnèní údaju smènečné sumy a data splatnosti, a remitentovi ji prédali, platí, že mu konkludentnè udělili právo blankosmènku doplnit i obledně data vystavení." Rozsudek Nejvyššího soudu ze dne 17. 12. 2008, sp. zn. 29 Odo 1621/2006.

14 KOVAŘíK, Zdeněk. Vznik, podstata a zánik práva vyplnit blankosměnku. Právni roz̧hledy, Praha: C. H. Beck, 2007, roč. 15, č. 1, s. 12.

15 SEDLAČKO, František. Blankozmenka a právo na jej vyplnenie (prvá část). Bulletin slovenskej advokacie, Bratislava: Slovenská advokátská komora, 2011, roč. XVII, č. 7-8, s. 14. Tyto charakteristické znaky vychází od Grünhuta, který jej charakterizuje jako samostatné, neodvolatelné, ne pouze osobní, ale zděditelné a převoditelné majetkové právo, vyplněním prázdných míst dohotovit směnku a uplatnit práva z blankosměnky. GRÜNHUT, C. S. Lehrbuch des Wechselrechts. Lepizig: Verlag von Duncker Humblot, 1900, s. 110.

16 H. Köhler uvádí (ve volném překladu autorky): „Blankosmènka mưže plnit svoji funkci v hospodářrkém životě pouze tehdy, pokud nabyvatel blanketu müže divvěrovat, že on nebo jeho právni nástupce mirže kedykoli blanket doplnit a vytvorit tak platnou smènku, aniž by se ho dotkly jakékeli možné neznámé okolnosti v osobè vydavatele blanketu“. KÖHLER, Helmut. Haftungsfragen beim Blankowechsel, fehlerhaften Wechsel und verfälschten Wechsel. Juristische Arbeitsblätter, Berlin: J. Schweiter Verlag, 1977, č. 1, s. 2.

17 KOVAŘÍK, Zdeněk. Smènka a šek v Ceské republice. 6. vyd. Praha: C. H. Beck, 2011, s. 119. ISBN 978-7400-402-5. 
Směnečné vyplňovací právo je vlastním právem nabyvatele blankosměnky, který toto práva vykonává svým jménem a ve svůj prospěch. Oprávněný ze směnečného vyplňovacího práva není zmocněncem výstavce blankosměnky; doplněním blankosměnky nevykonává právo výstavce blankosměnky, nýbrž svoje vlastní právo, které mu bylo uděleno. Charakter vyplňovacího práva jako vlastního práva nabyvatele blanketu umožňuje nabyvateli blanketu realizovat vyplňovací právo i poté, co výstavce blanketu zemřel, nebo pokud byla jeho svéprávnost dodatečně omezena. ${ }^{18}$

Dalšími charakteristickými rysy směnečného vyplňovacího práva jsou jeho prevevoditelnost a děditelnost. Převoditelnost a děditelnost vyplňovacího práva vychází z jeho majetkové povahy. Převoditelnost vyplňovacího práva úzce souvisí s převoditelností a děditelností blankosměnky, která jako předmět vlastnického práva může být, při respektování její formy, dále převáděna, př́padně může být zděděna. Pokud by společně s blankosměnkou nebylo možné převádět i vyplňovací právo, došlo by k oddělení blankosměnky od vyplňovacího práva, tedy ke ztrátě pojmového znaku blankosměnky a i ke ztrátě její ekonomické hodnoty, nebot' nabyvatel by již nikdy nemohl po právu přeměnit blankosměnku na hotovou směnku.

S převoditelností úzce souvisí i další charakteristický znak. Směnečné vyplňovací právo bývá označováno jako právo akcesorické, které zásadně není možné od blankosměnky oddělit. ${ }^{19}$ Akcesorita je tedy vyjádřením úzké vazby směnečného vyplňovacího práva a blankosměnky jako blankolistiny. Z akcesorické povahy směnečného vyplňovacího práva pak Z. Kovařík ${ }^{20}$ i judikatura ${ }^{21}$ dovozuje, že společně s převodem či přechodem blankosměnky dochází i $\mathrm{k}$ převodu či přechodu tohoto práva, aniž by bylo třeba ohledně něj uzavírat samostatnou smlouvu. Mám za to, že odpověd’ na otázku, zda s převodem či přechodem blankosměnky dochází bez dalšího i převodu či přechodu vyplňovacího práva, je třeba hledat spíše než ve vazbě vyplňovacího práva na blankosměnku v charakteru vyplňovacího práva a jeho vazbě na obsah závazku vzniklého z dohody o směnečném vyplňovacím právu. Tuto úvahu však s ohledem na rozsah textu ponechám stranou.

18 KAPFER, Hans. Wechselgestz und Scheckegesetz. 6. vyd. Wien: Manzsche Verlangs- und Universitätsbuchhandlung, 1967, s. 68.

19 SEDLAČKO, František. Blankozmenka a právo na jej vyplnenie (prvá část). Bulletin slovenskej advokacie, Bratislava: Slovenská advokátská komora, 2011, roč. XVII, č. 7-8, s. 14; KOVAříK, Zdeněk. Směnka a šek v České republice. 6. vyd. Praha: C. H. Beck, 2011, s. 120; CHALUPA, Radim. Zákon smènečný a šekový. 2. vyd. Praha: Linde Praha, a. s., 2006, s. 93. ISBN 80-7201-570-2.

20 KOVǍ̌íK, Zdeněk. Smènka a šek v Ceské republice. 6. vyd. Praha: C. H. Beck, 2011, s. 120. ISBN 978-7400-402-5.

21 Rozsudek Nejvyššího soudu ze dne 24. 9. 2008, sp. zn. 29 Odo 1407/2006, publikováno se Sbírce soudních rozhodnutí pod číslem 89/2009. 


\section{Názory na podstatu směnečného vyplňovacího práva v české a slovenské odborné literatuře}

Žádný z níže citovaných autorů výslovně neřadí vyplňovací právo mezi směnečná práva. Naopak, směnečné vyplňovací právo je většinově považováno za právo obecně právní, jehož podstatou je doplnit blankosměnku a přeměnit ji tak na směnku úplnou. Ohledně jeho povahy jsou zde však zastoupeny již různé názory - od názorů, že se jedná o právo utvářecí, přes zmocnění až po právo sui generis.

Mezi autory řadící směnečné vyplňovací právo mezi práva utvářecí patři R. Chalupa, R. Šnyrch a B. Jablonka. „Vyplňovaci oprávnèní má charakter práva utvárecího, na jebož základě lze jednostranným úkonem dohotovit dvoustranný nebo vícestranný závazkový vžtah, jebož základy byly položeny jedním nebo vice predcházejicimi právnimi úkony. Vyplňovaci oprávnèní je samostatným, neodvolatelným, dèditelným a preveditelným právem majetkové povahy dohotovit blankosmènku na úpl-

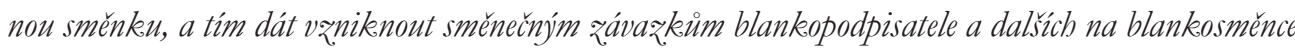
podepsaných osob (pokud ovšem jejich závazky již nevznikly drive podpisem blankosmènky obsahujicí všechny podstatné smènečné náležitosti). “22 Práva utvářecí, a tedy ani směnečné vyplňovací právo, nelze podle nich zařadit ani mezi práva věcná, ani mezi práva obligační. B. Jablonka odvozuje povahu tohoto práva od skutečnosti, že opravňuje majitele blankosměnky, aby jednostranným úkonem způsobil vznik směnky. ${ }^{23} \mathrm{R}$. Šnyrch označuje směnečné vyplňovací právo jako právo obecně-právní a zvláštní právo majetkové-utvářecí. ,Jeho podstata záleži v tom, že majitel blankosmènky je oprávnèn premènit nehotovou smènku na smènku hotovou pripojenim chybějicich podstatných náležitostí a obvyklých nebo smluvenyich doložek nepodstatných. Nejde o právo vècné vanikejici z titulu vlastnictvi smènky, se smènkou v'̌ak tèsnè souvisi a musí být vydavatel nehotové smènky jejímu nabyvateli udèleno. Nejde o právo smènečné ani typicky obligační, ale o právo obecně právni a zulástni právo majetkové - utvárecí.(...) Smènečný závazek je tak závislý na potestativni výmince dodatečnébo vyplnèní blankosmènky. “24

Závěr, že směnečné vyplňovací právo je právem utvářecím, výslovně odmítá Z. Kovařík. Sám jej považuje za právo obecně právní, za právo majetkové (vyjímá je přitom z obligacî), které má dvojí povahu - povahu věcného a smluvního práva. Zatímco věcné právo umožňuje majiteli nakládat s blankosměnkou jakýmkoli způsobem, a tedy do ní i cokoli doplňovat, smluvní povaha vyplňovacího práva představuje stanovení podmínek, při jejichž splnění dlužníci slibují výslednou směnku proplatit a naopak při nesplnění smluvených podmínek si vyhrazují placení odmítnout. „Toto smluvní vyplñovací právo není co do své povahy právem smènečným, nýbrž má charakter práva obecně právního, aniž by ovšem také v těchto

22 CHALUPA, Radim. Zákon smènéný a šekový. Komentár. 1. část. Smènky. 2. vyd. Praha: Linde Praha, 2006, s. 92. ISBN 80-7201-570-2.

23 JABLONKA, Branislav. Zákon żmenkový a šekový. Komentár. Bratislava: Wolters Kluwer, 2017, s. 61. ISBN 978-80-8168-721-1.

24 ŠNYRCH, Roman. Teoretické aspekty blankosměnky. Právní roz̧hledy, Praha: C. H. Beck, 1996, roč. 4, c. 12 , s. 544 . 
právnich predpisech bylo zulástè upraveno. Není právem obligačnim. Je to speciálni majetkové právo. Jeho výkon je jednostranný. (...) Podstata tohoto práva ležzi v oprávnèni majitele blankosmènky svým úkonem, to je doplnènim chybějicich častí, a to jak náležritostí podstatných, tak i doložek fakultativnich, premènit nehotový zárodek smènky na skutečný cenný papir, to je úplnou smènku. (...) Právo vyplnit blankosmènku ov̌̌em neni právem v blankosmènce vtěleným. Ta ostatně neni zatím smènkou ani cenným papírem. Jde o právo stojici vedle smènky. Nejde ovšem o právo zcela samostatného, toto právo je s blankosmènečnou listinou akecesoricky spojeno. Nemüže existovat právo vyplnit listinu, k.terá neexistuje. " 25

V. Nejedlý píše o zmocnění k vyplnění blankosměnky, přičemž zmocňovací prohlášení představuje nezbytný doplněk odevzdání blankosměnky. ${ }^{26} \mathrm{~J}$. Kotásek v souvislosti s povahou směnečného vyplňovacího práva uvádí: „Vyplňovaci smènečné či šekové právo nemá v českém právu obdobu. Bývá označováni jako právo sui generis, cožje spiše než. výstižnou charakteristikou vyjádřením ažptřliš mnoha nejasností, keteré tento právní institut v₹buzuje. “27

K povaze směnečného vyplňovacího práva se vyjadřovala i dřivější odborná literatura. K. Hermann-Otavský odvozuje povahu směnečného vyplňovacího práva z teorie vlastnického nabytí. „Z teorie vlastnického nabytí lze odivvodniti závazele blankopodpisatele prostè tím, že provedl skripturni akt zuistavuje jïným osobám určení jeho obsahu; uskutečni-li se dalši podminky pro vanike smènečné obligace, trebas bez jeho spoluprisobeni, vznikne jeho závazek, a nemư̌e poctivému nabyvateli vyplnènébo papíru namitati, že obsah smènky s jeho violi nesoublasí. Nesoublas tento nečini skeripturni aket nepravým; exceptio falsi (jež puisobi in rem, proti každému, tedy i proti poctivému nabyvateli) tu nemá mista. Z tohoto blediska jest prïpustiti i vanik qávaqku blankopodpisatele prázdného papiru, kdyžz nèho dodatečně byla utvořena smènka, a to i tenkráte, kdy žpodpisatel vỉbec na smènku nepomýšlel." ${ }^{28}$ Tuto teorii pak staví vedle teorií mandátních, teorií suspendovaného závazku směnečného, či teorií o „,vyplňovacím“, resp. „zásahovém“ práv nabyvatele blankosměnky (Ausfüllungsrecht, Eingriffsrecht).

G. Švamberg označuje vyplňovací právo jako zvláštní právo utvářecí, které je odlišné od věcných a obligačních práv. Podstatou zvláštních utvářecích práv je jednostranným projevem vytvoření nového právního poměru. Do stejné skupiny zakládacích práv utvářecích se pak řadí i právo opční. A podstatou směnečného vyplňovacího práva je přitom oprávnění majitele doplnit nehotovou směnku a přeměnit ji tak na směnku hotovou. Současně doplnění blankosměnky není výkonem jeho vlastnického práva, „(...) nýbrž̃ predpokládá, že mu bylo udèleno podpisatelem, ježto by majitel jinak zasahoval neoprávnènè do právní

25 KOVAŘíK, Zdeněk. Smènka a šek v České republice. 6. vyd. Praha: C. H. Beck, 2011, s. 118. ISBN 978-7400-402-5.

26 NEJEDLÝ, Václav. Blankosměnka. Právník, 1946, roč. 85, č. 1-2, s. 55.

27 KOTÁSEK, Josef. Zákon smènéný a šekový. Komentár. 2. akt. vyd. Praha: Wolters Kluwer, 2017, s. 109. ISBN 978-80-7552-544-4.

28 HERMANN-OTAVSKÝ, Karel. Ceskoslovenské právo smènečné podle všeobecnébo smènečnébo rádu. Praha: Všehrd, 1926, s. 35. 
sféry podpisatelovy vyvoláváním v život jeho smènečné obligace. “29 G. Švamberg dále směnečné vyplňovací právo charakterizuje jako právo neodvolatelné, zděditelné, převoditelné a přenositelné majetkové zakládací právo utvářecí, které „(...) neni právem samostatným, ale je spojeno s listinou, jejímž vlastnictvím je podminèno" ${ }^{30}$ Podobně považují směnečné vyplňovací právo za utvářecí právo i K. Kizlink a J. Spišiak, byt’ jej označují za právo tvořivé (Gestaltungsrecht). Toto právo podle nich opravňuje majitele blankosměnky, aby jednostranným úkonem (splněním předpokladu vzniku směnečné obligace) způsobil vznik směnečného práva. ${ }^{31}$

S. Štěpina pak s odkazem na rozhodnutí Sb. Vážný č. 11.216 nepopisuje podstatu směnečného vyplňovacího práva, ale v souvislosti s ním uvádí, že ,(s)měnečný qávaẓek nevzniká již blankoscripturním aktem, nýbržjeho vanike je závislý na potestativní výmince dodatečnébo vyplnèní smènky podle úmluvy".32

$\mathrm{V}$ české odborné literatuře se tedy na povahu směnečného vyplňovacího práva vyskytují různé názory, aniž by bylo možné říci, který názor je převažující. Objevují se závěry, že směnečné vyplňovací právo je právem utvářecím, obecně právním, právem sui generis i zmocněním.

\section{Zahraniční názory}

\subsection{Německá doktrína}

Německá odborná literatura definuje blankosměnku jako směnečnou listinu, která byla záměrně vydána jako neúplná, a k jejímuž doplnění (zkompletování) byl nabyvatel (př́íjemce) zmocněn jejím vydavatelem (vystavitelem). ${ }^{33}$ Objevují se názory raadící směnečné vyplňovací právo mezi práva utvářecí, ale i $\mathrm{k}$ zmocnění či připodobnění k potestativní podmínce.

Baumbach, Hefermehl a Casper považují vyplňovací právo za právo utvářecí (Gestaltungsrecht). Podle nich se jedná o zmocnění k vyplnění, které získává nabyvatel blankosměnky. Nabyvatel tak má právní moc, aby doplněním blanketu umožnil vznik směnečné pohledávky proti výstavci blanketu. Při vyplnění blanketu obvykle nejedná jako zástupce na základě plné moci, ale na základě vlastního práva. Autoři se současně vypořádávají s případnou námitkou, že podle německého práva neexistuje zmocnění

29 ŠVAMBERG, Gustav. Naše jednotné směněné právo. Praha: V. Palásek a Frant. Kraus, 1941, s. 220.

30 ŠVAMBERG, Gustav. Naše jednotné smènečné právo. Praha: V. Palásek a Frant. Kraus, 1941, s. 221.

31 KIZLINK, Karol a Ján SPIŠIAK. Zmenkové právo podle qákona č. 255/1941 Sl. U. Bratislava: Právnická jednota v Bratislave, 1944, s. 85.

32 ŠTĚPINA, Jaroslav. Směnka a směnečné rírení. Praha: Josef Svoboda, 1933, s. 35.

33 BAUMBACH, Adolf, Wolfgang HEFERMEHL a Matthias CASPER. Wechselgesetz, Scheckgesetz. 23. vyd. München: C. H. Beck, 2008, s. 139. ISBN 978-3-406-55284-7. „Der Blankowechsel ist eine bei Begebung bewusst unvollständige Wechselurkunde, zu deren Vervollständigung der Geber den Nehmer ermächtigt hat." 
$\mathrm{k}$ povinnosti. Zvláštnost zmocnění $\mathrm{k}$ vyplnění spočívá podle nich $\mathrm{v}$ tom, že vydavatel blanketu již směnečnou povinnost založil vydáním blankosměnky, a to skrze smlouvu o vydání cenného papíru, která je vyplněním konkretizována. Př́ijemce blankosměnky činí jejím vyplněním podle své vưle právní jednání, které je nutné pro účinnost směnky. ${ }^{34} \mathrm{~V}$ předchozím vydání této knihy z roku 2000 autoři směnečné vyplňovací právo za právo utvářecí neoznačují. Závěr, že směnečné vyplňovací právo je právem utvářecím, se výslovně objevuje až ve 23. vydání citovaného komentáře.

K jinému závěru dochází autoři P. Bülow a H. Köhler. Oba považují směnečné vyplňovací právo za zmocnění. P. Bülow ${ }^{35}$ označuje vyplňovací právo jako zmocnění k doplnění (Ermächtigung zur Vervollständigung). Toto zmocnění je podle něj jednostranný projev vi̊le, který nevyžaduje přijetí a pro který není vyžadována žádná forma. Zmocněnec (oprávněný ze směnečného vyplňovacího práva) pak jedná vlastním jménem, nikoli jménem vydavatele blanketu, a vykonává vlastní právo (to však nevylučuje možnost, aby doplnění bylo realizováno jménem výstavce blanketu, a to v případě, že nabyvatel blanketu je současně jeho zástupcem v obchodovánî). Směnečná povinnost vzniká jen v rozsahu, v jakém vyplnění odpovídá dohodě. Odpovědnost jdoucí nad rámec dohody zakládá ve smyslu čl. 10 nikoli toto zmocnění, nýbrž se opírá o přičitatelná zákonná domnělá práva. H. Köhlerr ${ }^{36}$ uvádí, že nabyvatel blanketu je schopen založit povinnost výstavce blanketu. Toto odůvodňuje oprávněním k vyplnění (Ausfüllungsbefugnis), které mu výstavce blanketu propůjčil. Oprávnění je judikaturou zpravidla považováno za zmocnění (Ermächtigung), tedy za neodvolatelné vlastní právo prújemce blanketu k vyplnění, jen výjimečně za plnou moc. Upozorňuje, že dogmatický základ není zcela jednoznačný. Správně by se mělo rozlišovat mezi aktem doplnění směnečné listiny a uskutečněním odpovídajícímu dohodě o vydání cenného papíru. Vyplnění jako takové je reálným aktem. To, kdo vyplnění uskuteční, není pro otázku formální platnosti významné. Není proto ani rozhodující, zda se vyplnění uskuteční vlastním nebo cizím jménem.

A. Hueck a C. W. Canaris poukazují na spornost právní povahy vyplňovacího oprávnění. Připouští, že vyplňovací oprávnění je utvářecím právem, nebot’ existuje kategorie vyplňujících utvářecích práv. Na druhou stranu však poukazují na to, že utvářecí práva mají tendenci působit jenom mezi oprávněným a „povinným“, avšak zde realizací vyplňovacího práva často vznikají i vztahy mezi vydavatelem blanketu a třetími osobami. ${ }^{37}$

34 BAUMBACH, Adolf, Wolfgang HEFERMEHL a Matthias CASPER. Wechselgesetz. Scheckegeset\%. 23. vyd. München: C. H. Beck, 2008, s. 142. ISBN 978-3-406-55284-7.

35 BÜLOW, Peter. Wechselgesetz. Scheckegesetz. 5. vyd. München: C. H. Beck, 2013, s. 69. ISBN 3-8114-1920-X.

36 KÖHLER, Helmut. Haftungsfragen beim Blankowechsel, fehlerhaften Wechsel und verfälschten Wechsel. Juristische Arbeitsblätter, Berlin: J. Schweiter Verlag, 1977, č. 1, s. 2.

37 HEUCK, Alfred a Claus-Wilhelm CANARIS. Recht der Wertpapiere. 12. vyd. München: Vahlen, 1986, s. 119. ISBN 3800611724. 


\subsection{Rakouská doktrína}

H. Kapfer označuje směnečné vyplňovací právo jako zmocnění př́ijemce k vyplnění. ${ }^{38}$ Uvádí, že směnečná povinnost nevzniká ještě vydáním blankosměnky, nebot' její vznik je závislý na potestativní podmínce dodatečného vyplnění blankosměnky (se zpětnými účinky k okamžiku podpisu blanketu).

Jako zmocnění označuje směnečné vyplňovací právo i M. E. Feil, konkrétně jako zmocnění vytvořit úplnou směnku. Blíže se však povahou tohoto práva nezabývá. ${ }^{39}$ Obdobně pak směnečné vyplňovací právo popisuje i W. Hauser s odkazem na judikaturu. ${ }^{40}$ H. Keinert pak poukazuje na spornou povahu směnečného vyplňovacího práva. ${ }^{41}$

\section{3 Švýcarská doktrína}

Autoři P. Jäggi, J. N. Druey a Ch. von Greyerz označují směnečné vyplňovací právo jako zmocnění k vyplnění směnky (die Ermächtigung zum Ausfüllen eines Wechsels). Toto zmocnění však současně odlišují od plné moci ve smyslu obligačního práva s odůvodněním, že osoba, která blankosměnku vyplňuje, jedná vlastním jménem, vykonává vlastní právo, nikoli právo výstavce blanketu, tedy nejedná v jeho zastoupení. Proto může být blankosměnka doplněna i tehdy, pokud se výstavce blanketu stane nesvéprávným, spadne do konkurzu nebo zemře. Zmocnění je také neodvolatelné. Teoreticky je proto blanket delegace (eine Delegation) a její odůvodnění musí vycházet z tehdejší právní pozice, která má být delegována. $\mathrm{V}$ důsledku toho je tak zmocnění k vyplnění směnečněprávní institut a podle převažujícího mínění se na něj v př́padě nedostatku zákonné úpravy uplatní zásady směnečného práva. ${ }^{42}$ Delegace přitom může znamenat i převzetî povinnosti. V př́padě blanketu se jedná o delegaci práva (können), ledaže by bylo ujednáno jinak. ${ }^{43}$

38 KAPFER, Hans. Wechselgestr, und Scheckegeset\%. 6. vyd. Wien: ManzscheVerlangs- und Universitätsbuchhandlung, 1967, s. 66.

39 FEIL, Mag Erich. ABC des Wechselrechts. Wien: Linde, 2002, s. 46. ISBN 3-7073-0335-7.

40 HAUSER, Werner. Österreichisches Wechsel-und Scheckerecht. 2. vyd. Wien: Verlag Österreich, 1999 , s. 36. ISBN 978-3-7046-1442-1.

41 KEINERT, Hans. Handbuch des Wertpapierrechts. nach österreichischem und deutschem Recht. Band 1. Wien: Verlag Österreich, 2014, s. 320. ISBN 978-3-7046-6602-4.

42 JÄGGI, Peter, Jean Nicolas DRUEY a Christoph VON GREYERZ. Wertpapierrecht unter besonderer Berücksichtigung von WECHSEL und CHECK. Basel: Verlag Helbing \& Lichtenbahn, 1985, s. 162. ISBN 9783719009120.

43 JÄGGI, Peter, Jean Nicolas DRUEY a Christoph VON GREYERZ. Wertpapierrecht unter besonderer Berücksichtigung von WECHSEL und CHECK. Basel: Verlag Helbing \& Lichtenbahn, 1985, s. 162. ISBN 9783719009120. Ke stejnému závěru s odkazem na závěr přijatý v uvedené publikaci dospívá i Claudia Sieber, která uvádí, že delegace znamená převzetí práv a povinností, v případě blanketu se však týká pouze „moci“ (können) a nikoli muset (müssen). SIEBER, Claudia. Schweizerischer Wechsel - U. S. Bill of Exchange und Promissory Note. Zürich: Schultess Polygraphischer Verlag AG, 1995, s. 22. 
K povaze vyplňovacího práva jako o delegace se rovněž kloní M. Grüninger, B. Hunziker a G. Roth se stejným odůvodněním. Vyplňovací právo dále charakterizují jako vedlejší právo (das Nebensrecht), které je s blankolistinou spojeno a jako vedlejší právo pak přechází společně s převodem směnky na následujícího nabyvatele směnky. Nejedná se podle nich o vysoce osobní právo (höchstpersönliches Recht), nebot' doplnění smí být vykonáno osobou odlišnou od př́jemce blanketu. Doplnění je možné také po smrti, nesvéprávnosti či konkurzu výstavce. Právo k vyplnění opravňuje také k tomu určit den splatnosti. ${ }^{44}$

\section{Směnečné vyplňovací právo a podmíněný směnečný závazek}

V souvislosti se směnečným vyplňovacím právem bývá zmiňována potestativní podmínka dodatečného vyplnění blankosměnky, resp. že směnečný závazek je závislý na výmince dodatečného vyplnění blankosměnky. ${ }^{45}$ Mám za to, že spíše než o otázku povahy směnečného vyplňovacího práva se jedná o otázku vlivu realizace vyplňovacího práva na vznik směnečných povinností, resp. směnky. Přesto bych se této otázce, s ohledem na četnost spojení vyplňovacího práva a podmínky, ráda věnovala podrobněji.

Podmínku, která bývá zmiňována $\mathrm{v}$ souvislosti se směnečným vyplňovacím právem, nelze zaměňovat s požadavkem čl. I 1 ZSŠ na bezpodmínečnost př́kazu/slibu. Směnka bývá charakterizována jako bezpodmínečný cenný papír, její zaplacení tedy nemůže být vázáno na žádnou podmínku. Platnost směnky maří jakákoli podmínka, je irelevantní, zda se jedná o podmínku odkládací či rozvazovací splnitelnou či nesplnitelnou, subjektivní či objektivní. Jako př́klad takové podmínky uvádí J. Kotásek doložku „Zaplatte po dodání z̧bož̃ ${ }^{*}{ }^{46}$ Podmínky mařící platnost směnky se tedy týkají okolností, za nichž se zavazuje dlužník svůj závazek ze směnky splnit, tedy na směnku zaplatit. Podmínka související s blankosměnkou však nesměřuje $\mathrm{k}$ vymezení okolností, za nichž dlužník směnku zaplatí, ale ke vzniku směnky jako takové. Pokud by však blankosměnka obsahovala doložku „Zaplat'te po dodáni zbožz a taková blankosměnka by byla doplněna v souladu s dohodou o směnečném vyplňovacím právu, platnou směnkou se stejně nestane.

Podmínka zmiňovaná $\mathrm{v}$ souvislosti se směnečným vyplňovacím právem směřuje ke vzniku směnky z blankosměnky, tedy k jejímu doplnění. Blankosměnka se stává směnkou až v okamžiku, kdy je doplněna a splňuje alespoň minimální náležitosti, které zákon

44 GRÜNINGER, Marc, Bruno HUNZIKER a Gerhard ROTH. Art. 1000 OR. In: HONSELL, Heinrich, Peter Nedim VOGT, Rolf WATTER a kol. Basler Kommentar. Wertpapierrecht. Basel: Helbing Lichtenhahn Verlag, 2012, s. 139. ISBN 978-3-7190-3088-9.

45 H. Kapfer s odkazem na judikaturu uvádí (ve volném překladu autorky): Směnečné povinnosti nevznikají blankoskripturním aktem, jejich vznik (se zpětnými účinky k vyhotovení blanketu) závisí na potestativní podmínce smluvního doplnění blanketu. KAPFER, Hans. Handkommentar zum Wechselgesetz. Wien: Manzsche Verlangs- und Universitätsbuchhandlung, 1960, s. 64.

46 KOTÁSEK, Josef. Zákon smènéný a šekový. Komentár. 2. akt. vyd. Praha: Wolters Kluwer, 2017, s. 37. ISBN 978-80-7552-544-4. 
pro směnku cizí nebo vlastní předepisuje. Dokud není blankosměnka doplněna, stále je směnkou neúplnou, resp. není směnkou vưbec. Znamená to tedy, že s doplněním blankosměnky je spojen vznik směnky a tedy i směnečných závazků, nikoli vyvolání účinků perfektního právního jednání, tedy vyvolání účinků již úplné a platné směnky. Nelze proto podle mého názoru hovořit ani o podmíněné směnečné pohledávce ve smyslu podmínek v režimu \528 a násl. zákona č. 89/2012 Sb., občanský zákoník (dále jen OZ). Podstatou těchto podmínek je totiž skutečnost, že účastníci soukromoprávního vztahu rozdělí okamžik uskutečnění, resp. závaznosti právního jednání a jeho účinků. Tedy že v prrípadě potestativních podmínek odloží účinky jinak perfektního právního jednání. $\mathrm{V}$ prípadě blankosměnky se však o úplnou směnku, z níž by plynuly povinnosti dlužníků směnku zaplatit, prozatím nejedná. U podmínek je nastoupení právních účinků závislé na nějaké vnější okolnosti. „Mohou tak vázat účnkey svých právnich jednáni na splnèni v budoucnu nastanuvǐich skutečností, o kteryich v̌̌ak prì uskutečnèni tohoto právního jednáni neni jisté, zda nastanou, př̆padně kdy nastanou. Nejistota je blavním znakem podminky. “" ${ }^{* 47}$

Doplnění blankosměnky pak nemůže být za splnění podmínky považováno podle mého názoru ani s ohledem na časový okamžik, od nějž vyvolává právní jednání právní účinky. Při splnění podmínky vyvolává právní jednání právní účinky až od okamžiku, kde ke splnění podmínky došlo, zatímco $\mathrm{v}$ případě doplnění blankosměnky dochází $\mathrm{k}$ přeměně na hotovou směnku s účinky ex tunc. ${ }^{48}$

Pokud jde o podmíněnou směnečnou pohledávku, nejedná se tedy o podmínky ve smyslu zákona směnečného a šekového. Nebot’ slib či př́kaz tvořící směnku nemůže být podmíněný. Současně se ale nejedná ani o podmínku ve smyslu $\int 548$ OZ. Pak by to totiž znamenalo to, že účinky splnění odkládací podmínky by nastávaly až od okamžiku, kdy dojde ke splnění podmínky, tedy k okamžiku doplnění blankosměnky. Podmínka navíc bývá charakterizována jako objektivní skutečnost nezávislá na vưli, což v případě doplnění blankosměnky není splněno.

Doplnění blankosměnky je předpokladem vzniku směnky, a tedy i směnečných závazků. Směnka totiž vzniká z blankosměnky až v okamžiku, kdy blankosměnka byla doplněna alespoň takovými údaji, které jsou podle ZSŠ nezbytné k vydání platné směnky. Proto pokud má být v souvislosti s blankosměnkou hovořeno o podmíněné směnečné pohledávce, je tak možné pouze v širším smyslu pojmu podmínka. Tedy ve smyslu obecného

47 DOBROVOLNÁ, Eva a Jan HURDÍK. \548 [Podmínka, podmínka odkládací a rozvazovací, podmínka nemožná]. In: LAVICKÝ, Petr a kol. Občanský zákonik I. Obecná část (\$ 1-654). Praha: C. H. Beck, 2014, s. 1957. ISBN 978-80-7400-529-9.

48 DOBROVOLNÁ, Eva a Jan HURDÍK. $\int 548$ [Podmínka, podmínka odkládací a rozvazovací, podmínka nemožná]. In: LAVICKÝ, Petr a kol. Občanský zákonike I. Obecná cást (』 1-654). Praha: C. H. Beck, 2014, s. 1959. ISBN 978-80-7400-529-9. „Sjednáním odkládaci podmínky nastávaji ex nunc úcinky právníbo jednání jejim splnènim, kterým je stav nejistoty ukončen." 
předpokladu, na jejímž splnění nutně něco závisí. ${ }^{49}$ Tím však není dotčena možnost sjednat podmínky v samotné dohodě o směnečném vyplňovacím právu; tato ujednání ale budou mít vliv pouze na to, kdy bude samotná dohoda vyvolávat právní účinky, a tedy kdy bude moci oprávněný realizovat své směnečné vyplňovací právo. $V$ prrípadě nerespektování těchto ujednání $\mathrm{v}$ dohodě o směnečném vyplňovacím právu by bylo možné uvažovat o protismluvním doplnění blankosměnky.

\section{Směnečné vyplňovací právo jako zmocnění (zastoupení)}

Ztotožnění směnečného vyplňovacího práva se zmocněním se objevuje především v rakouské literatuře. Švýcarská doktrína již tento závěr o povaze směnečného vyplňovacího práva opouští a označuje je jako delegaci. V českém právním prostředí se jedná spíše o ojedinělý názor. ${ }^{50}$

V českém právním prostředí se zmocnění blíží zastoupení. Podle toho, na jakém základě zastoupení vzniká, se rozlišuje zastoupení zákonné (vzniká na základě zákona nebo na základě rozhodnutí orgánu veřejné moci) a smluvní (vzniká na základě dohody o plné moci). $\mathrm{V}$ prŕpadě vyplňovacího práva, které vzniká na základě dohody, přichází tedy v úvahu zastoupení smluvní. Vyplňovací právo vzniká na základě smlouvy, tedy stejně jako plná moc. Jeho smyslem je, stejně jako institutu zastoupení, „(...) umožnit, aby osoba, keterá je ke právním úkonuim jinak zpiisobilá, je mobla dát za sebe súcinky pro sebe cuinit někém jiným. " ${ }^{\text {"51 }}$

Avšak vyplňovací právo se od zastoupení rovněž v některých podstatných otázkách liší. Snad největší rozdíl je patrný v samotné podstatě zastoupení a vyplňovacího práva. Plná moc, na rozdíl od vyplňovacího práva, nezakládá subjektivní právo, ale propůjčuje oprávněnému jen způsobilost bezprostředně jednat za zmocnitele. ${ }^{52} \mathrm{Z}$ tohoto zásadního rozdílu v postavení nabyvatele vyplňovacího práva a zmocněnce plynou další odlišnosti. Nabyvatel vyplňovacího práva na rozdíl od zmocněnce vykonává své vlastní právo, které mu bylo vydavatelem uděleno, jedná svým vlastním jménem a na vlastní účet (v príípadě nepřímého zastoupení sice zmocněnec jedná vlastním jménem, ale na účet zastoupeného). V důsledku toho, že nabyvatel vykonává vlastní právo, nikoli právo vydavatele, mu toto právo svědčí např. i tehdy, byl-li vydavatel v mezidobí od vydání směnky

49 MELZER, Filip. Podmínka \528. In: MELZER, Filip, Petr TÉGL a kol. Občanský zákoník - velký komen-

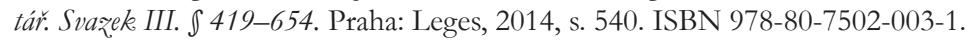

50 Jako zmocňovací prohlášení označuje směnečné vyplňovací právo V. Nejedlý. Viz NEJEDLÝ, Václav. Blankosměnka. Právník, 1946, roč. 85, č. 1-2, s. 55.

51 Smyslem zastoupení je i to, aby někdo jiný mohl činit právní úkony za osobu, která k nim není sama způsobilá. MELICHAROVÁ, Dita. Několik poznámek k problematice zastoupení na základě plné moci. In: DVOŘÁK, Jan a Jan KINDL. Pocta Martě Knappové k 80. narozeninám. Praha: ASPI, 2005, s. 279. ISBN 80-7357-133-1.

52 WOLF, Manfred a Jörg NEUER. Allgemeiner Teil des Bürgerlichen Rechts. 11. přepracované vyd. München: C. H. Beck, 2016, s. 224. ISBN 9783406696985. 
do jejîho doplnění omezen ve svéprávnosti. Rozhodující je vždy okamžik udělení tohoto práva. Naopak v případě smluvního zastoupení musí mít způsobilost k právním úkonům jak zástupce, tak zastoupený, a to nejen k udělené plné moci, ale i k úkonu, který má být za zastoupeného proveden. Stejně tak nebude mít vliv na právo doplnit blankosměnku př́padná smrt toho, kdo nabyvateli právo udělil. Naopak v prrípadě smrtí zastoupeného plná moc zaniká. Dalším podstatný rozdíl spočívá v převoditelnosti. Zatímco směnečné vyplňovací právo je převoditelné, a to společně s blankosměnkou, zastoupení převoditelné není, zástupce musí jednat osobně, dalšího zástupce si může ustanovit, pouze pokud to připouští právní předpis nebo pokud to bylo mezi účastníky ujednáno. Plná moc je dále, na rozdíl od vyplňovacího práva odvolatelná.

Vydavatel blankosměnky tedy neuděluje jejímu nabyvateli plnou moc k tomu, aby jej nabyvatel zastupoval, tedy aby vykonal práva zmocněnce, at' již jeho nebo vlastním jménem. Nabyvatel blankosměnky vykonává vyplňovací právo svým vlastním jménem a na svůj účet, vykonává svoje vlastní právo. Nemůže se tedy jednat o zmocnění ve smyslu \436 OZ, tedy o prímé zastoupení, ani o zastoupení nepřímé např̀. ve smyslu komise. Vydavatel blankosměnky totiž vykonává své vlastní právo, které mu bylo vydavatelem blankosměnky uděleno. Tím však není dotčena možnost, aby se oprávněný ze směnečného vyplňovacího práva při doplnění blankosměnky nechal zastoupit.

\section{Směnečné vyplňovací právo jako utvářecí právo (kreační, kompetenční oprávnění)}

V předchozích kapitolách bylo popsáno, čím směnečné vyplňovací právo není. Směnečné vyplňovací právo není podmínkou, resp. doplnění blankosměnky není podmínkou ve smyslu \528 a násl. OZ. Směnečné vyplňovací právo není ani zmocněním, nebot' výstavce blanketu neuděluje jeho nabyvateli plnou moc k doplnění blankosměnky. Další z označení, které bývá v souvislosti se směnečným vyplňovacím právem zmiňováno, je utvářecí právo.

S označením utvářecí právo (Gestaltungsrecht) se lze setkat zejména v německé odborné literatuře. Avšak i někteři čeští autoři řadí směnečné vyplňovací právo mezi práva utvářecí. ${ }^{53}$ Zatímco však německé právo má pojem utvářecích práv poměrně podrobně zpracovaný v obecné rovině, v české literatuře se s ním lze setkat pouze zřídka. Zatímco $\mathrm{v}$ německé literatuře vede zařazení směnečného vyplňovacího práva mezi utvářecí práva k vyjasnění jeho podstaty a některých jeho charakteristických znaků, v českém právním prostředí spojení vyplňovací práva s právem utvářecím $\mathrm{k}$ vyjasnění jeho podstaty př́iliš nedochází. Na rozdíl od německé doktríny, která má problematiku utvářecích práv

53 CHALUPA, Radim. Zákon smènéný a šekový. Komentár. 1. část. Smènky. 2. vyd. Praha: Linde Praha, 2006, s. 92. ISBN 80-7201-570-2; ŠNYRCH, Roman. Teoretické aspekty blankosměnky. Právní roẓledy, Praha: C. H. Beck, 1996, roč. 4, č. 12, s. 544. 
poměrně podrobně zmapovanou, v českém právním prostředí zůstává tato problematika stranou pozornosti.

Německá odborná literatura řadí utvářecí práva mezi subjektivní práva, k nimž v kontrapozici nestojí konkrétní právní povinnosti jiné osoby, ale povinnosti $\mathrm{v}$ tom smyslu, že člověk musí strpět jednání oprávněného, aniž by se proti němu mohl bránit (Gebundenheiten). ${ }^{54}$ Utvářecí právo je právo náležející určité osobě, jehož obsahem je právo vlastním jednostranným utvářecím aktem, většinou jednostranným právním jednáním, právo mezi ním a jinou osobou vytvořit, konkretizovat jeho obsah nebo je změnit či zrušit. Utvářecí právo se vykonává zpravidla prohlášením vưči jeho vydavateli, který musí být o právní změně uvědomen. Zpravidla se proto jedná o projevy vưle, které potřebují přijetí. Podle toho, zda se jedná o práva samostatná či nikoli, jsou tato práva samostatně převoditelná. Zásadně jsou utvářecí práva neodvolatelná.

Obdobu německých utvářecích práv lze v českém právním prostředí spatřovat v kreačních oprávněních, kompetenčních oprávněních a koneckonců i utvářecích právech. S označením kreační oprávnění pracuje F. Melzer, pojem kompetenční oprávnění používá M. Hulmák a s utvářecími právy se lze setkat ve směnečněprávní doktríně. Podle jejich popisu se však ve všech třech případech jedná o totéž. Systematické zpracování však chybí. Kreační oprávnění „(...) spočivaji v tom, že opravñuji k bezprostrednímu prisobení na právni poméry v podobě vaniku, zmèny nebo jejich zániku. “55 $\mathrm{Na}$ rozdíl od nároků ve smyslu subjektivního práva na plnění, která se uplatňují u soudu, realizují se kreační oprávnění přímo hmotněprávním jednáním. Kreační oprávnění tvoří vedle pohledávky a dluhu obsah závazku. „Tato práva nejsou pobledávkami, nejde je samostatně postoupit, neprecházeji s pobledávkou, když se dotýkaji nejenom pobledávky, ale závazku jako celku, tedy i postaveni dlužnika. Tato práva nejsou právem na plnèni drubé strany. "56 Mezi kreační oprávnění se řadí právo odstoupit od smlouvy, vypovědět závazek, právo dovolat se relativní neplatnosti a opční právo. ${ }^{57} \mathrm{M}$. Hulmák k tomuto př́kladnému výčtu práv řazených ke kompetenčním oprávněním přidává ještě předkupní právo a potestativní podmínky. ${ }^{58}$ Bližší pozornost však utvářecím právům systematicky věnována není. Tato nekoncepčnost se pak promítá např. i v otázce promlčení utvářecích práv (dle německé úpravy podléhají utvářecí práva prekluzi), kdy je rozdílně přistupováno k promlčení různých utvářecích práv.

54 WOLF, Manfred a Jörg NEUER. Allgemeiner Teil des Bürgerlichen Rechts. 11. přepracované. vyd. München: C. H. Beck, 2016, s. 226. ISBN 9783406696985.

55 MELZER, Filip. Následky neplatnosti \586. In: MELZER, Filip, Petr TÉGL a kol. Občanský qákoník -

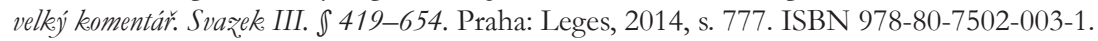

56 HULMÁK, Milan. \1721 [Právo na plnění]. In: HULMÁK, Milan a kol. Občanský qákoník V. Závazkové právo. Obecná cást (』 1721-2054). Praha: C. H. Beck, 2014, s. 4. ISBN 978-80-7400-535-0.

57 MELZER, Filip. Následky neplatnosti \586. In: MELZER, Filip, Petr TÉGL a kol. Občanský quákoník velký komentár. Svazek III. \419-654. Praha: Leges, 2014, s. 777. ISBN 978-80-7502-003-1.

58 HULMÁK, Milan. \1721 [Právo na plnění]. In: HULMÁK, Milan a kol. Obranský zákoník V. Závazkové právo. Obecná cást (』 1721-2054). Praha: C. H. Beck, 2014, s. 4. ISBN 978-80-7400-535-0. 
Př́kladem lze uvést různý prrístup $\mathrm{k}$ promlčení práva od smlouvy a práva vypovědět nájem na dobu neurčitou, které má sankční povahu. Zatímco právo odstoupit se promlčuje ${ }^{59}$, právo vypovědět nájem na dobu neurčitou promlčení nepodléhá, a to ani v př́ipadě, kdy se jedná o výpověd’ z důvodu nezaplacení nájemného ${ }^{60}$. Ačkoli tedy se tedy terminologie různí, všechna tři označení těchto práv mají stejnou podstatu. Já nadále budu používat pojem utvářecích práv.

Lze tedy jen velmi těžce podřadit směnečné vyplňovací právo do kategorie práv, která nejsou jednotně charakterizována, a tvoří spíše jen zbytkovou kategorii práv, kdy jejich vlastnosti popisovány samostatně bez ohledu na to, do jaké skupiny práv náleží. Přesto však alespoň ze dvou výše uvedených charakteristik lze dovodit, že utvářecí práva opravňují k jednostrannému působení na právní vztahy tak, že jednostranně umožňují jejich vznik, změnu nebo zánik, nejsou právem na plnění, nelze je tedy žalobou uplatnit u soudu, jsou neodvolatelná a zpravidla samostatně nepřevoditelná. Z těchto základních charakteristických rysů lze pak vyjít při podřazení směnečného vyplňovacího práva pod utvářecí práva.

Při vystavení blankosměnky dochází společně s vyhotovením a vydáním blankolistiny k uzavření dohody o vydání cenného papíru (v souladu s teorií domnělých práv) ${ }^{61}$. Tato dohoda o vydání cenného papíru, resp. blankosměnky nemá stejný obsah jako v př́padě, že je tato dohoda uzavírána při vydání směnky, nebot’ při vydání blankosměnky nebudou smluvním stranám zpravidla známy konkrétní náležitosti, resp. konkrétní obsah směnečného závazku. Obsah dohody o vydání cenného papíru nabývá konkrétních rozměrů až při doplnění blankosměnky. Vedle této dohody však vydavatel blankosměnky a její nabyvatel uzavírá další dohodu, dohodu o udělení směnečného vyplňovacího práva. Obsahem závazku z této dohody je právo nabyvatele doplnit blankosměnku stanoveným způsobem a za sjednaných podmínek, přičemž tomuto právu odpovídá „povinnost“ jejího vydavatele vyplnění strpět, resp. přijmout. ${ }^{62}$ Podstatou směnečného vyplňovacího práva je právo jeho nabyvatele doplnit blankosměnku, přičemž realizací vyplňovacího práva dochází ke vzniku směnečněprávního závazku. Směnečné vyplňovací právo není právem na plnění, jehož by bylo možné domáhat se u druhé smluvní strany a v případě jeho nesplnění u soudu. Vyplňovací právo opravňuje jeho nabyvatele způsobit vlastním jednáním vznik směnečného závazku. Obdobně může být tímto utvářecím právem

59 Rozsudek Nejvyššího soudu ze dne 16. 1. 2007, sp. zn. 30 Cdo 2047/2006, rozsudek Nejvyššího soudu ze dne 9. 12. 2004, sp. zn. 33 Odo 633/2003, rozsudek Nejvyššího soudu ze dne 4. 2. 202, sp. zn. 33 Odo $755 / 2001$.

60 Rozsudek Nejvyššího soudu ze dne 9. 12. 2010, sp. zn. 26 Cdo 78/2010.

61 MAREK, Radan. \520 Vydání cenného papíru. In: MAREK, Radan a Václav JEŽEK. Cenné papíry v novém občanském quákoníku. Praha: C. H. Beck, 2013, s. 38. ISBN 978-80-7400-466-7.

62 Srov. R. Chalupa, který rozlišuje mezi smlouvou o udělení vyplňovacího práva a smlouvou o vyplnění blankosměnky. CHALUPA, Radim. Vznik vyplňovacího oprávnění. Obchodní právo, Praha: Wolters Kluwer, 2019, roč. 28, č. 1, s. 29-40. 
např. právo odstoupit od kupní smlouvy, které vedle povinnosti převést vlastnické právo k předmětu kupní smlouvy, povinnosti zaplatit kupní cenu a práv tvořících protipól k těmto povinnostem tvoří obsah závazku z kupní smlouvy. Odstoupením od smlouvy, tedy jednostranným adresovaným právním jednáním, rovněž dochází k pưsobení na závazek, zde však, na rozdíl od směnečného vyplňovacího práva, dochází k zániku závazku.

Rozdíl mezi odstoupením od smlouvy, výpovědi či uplatnění opčního práva a doplněním blankosměnky je však ve výkonu těchto práv. Zatímco ostatní utvářecí práva se realizují hmotněprávním adresovaným právním jednáním, směnečné vyplňovací právo se realizuje faktickým jednáním, doplněním textu do blankolistiny. Podstata a důsledky však zůstávají stejné. Vlastním jednáním přivodit vznik, změnu nebo zánik závazku. Mám proto za to, že i přes rozdílnost způsobu výkonu tohoto práva, je co do účinků směnečné vyplňovací právo utvářecím právům nejbližší.

Bylo by možné namítnout, že v př́padě realizace směnečného vyplňovacího práva může dojít ke vzniku směnečného závazku, který je širší než to, co bylo mezi vydavatelem blankosměnky a jejím nabyvatelem ujednáno, tedy že $\mathrm{v}$ důsledku doplnění blankosměnky může vzniknout směnečný závazek nad rámec dohody. Bude se jednat o situace, kdy bude blankosměnka doplněna $v$ rozporu s dohodou o vyplňovacím právu. Směnečný závazek vznikne dlužníkovi i v př́padě, že svưj podpis umístí na směnku např. omylem, tedy bez dohody s věritelem, tedy i v prrípadě, že žádná dohoda uzavřena nebyla, a bude na dlužníkovi, aby se námitkami zaplacení takové směnky ubránil. Vưči třetím osobám v takovém prŕpadě vznik směnečného závazku nepramení z dohody, ale je třeba jej odůvodnit teorií domnělých práv. ${ }^{63}$

Dále se lze setkat s námitkou, že realizací vyplňovacího práva nedochází pouze ke vzniku závazku mezi tím, kdo vyplňovací právo udělil, a jeho nabyvatelem, resp. ke vzniku práva na zaplacení směnky věřitele vůči směnečným dlužníkům, ale i ke vzniku vztahů mezi směnečnými dlužníky vzájemně ${ }^{64}$ Pokud se jedná o mimosměnečné vztahy těchto dlužníků (nap̌r. v př́padě avalisty a jeho avaláta), tyto zpravidla vzniknou ještě před doplněním blankosměnky. Doplnění blankosměnky tedy může založit pouze směnečné vztahy mezi těmito osobami (např. regres avalisty vưči avalátovi). Mám za to, že ke vzniku těchto vztahů však dochází ze zákona $\mathrm{v}$ důsledku toho, že se z neúplné směnky stane směnka úplná. Vždyt' směnečné závazky mohou vzniknout, i když směnečný dlužník žádnou dohodu neuzavře (např. pokud aval umístí svůj podpis na směnku bez předchozí dohody s dlužníkem nebo věřitelem).

Rovněž by bylo možné namítnout, že u platebních blankosměnek (pro solvendo) je oprávněný ze směnečného vyplňovacího práva povinen blankosměnku doplnit, tedy

63 BÜLOW, Peter. Wechselgesetz: Scheckgesetz. 5. vyd. München: C. H. Beck, 2013, s. 56. ISBN 3-8114-1920-X.

64 Jedná se o hlavní námitku německých autorů, proč není možné zařadit směnečné vyplňovací právo mezi utvářecí práva. 
že směnečné vyplňovací právo má charakter povinnosti. Pokud bylo sjednáno placení prostřednictvím směnky ve smyslu \1909 OZ, má oprávněný „(...) povinnost požadovat

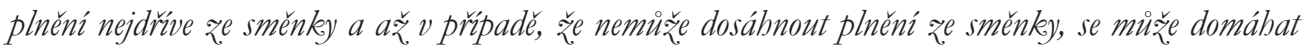
uspokojeni svých práv ze smlouvy. “65 Z této úpravy však povinnost $\mathrm{k}$ doplnění blankosměnky dovozovat nelze. Ustanovení pouze stanoví, že byla-li vydána směnka, věřitel má povinnost v prŕípadě, že bude požadovat plnění, učinit tak prostřednictvím směnky. Ustanovení mu však neukládá povinnost plnění skrze směnku požadovat. Obdobně je tomu v př́ípadě blankosměnky - z ustanovení nelze dovozovat povinnost blankosměnku vyplnit, ale $\mathrm{v}$ prrípadě, že věritel bude požadovat plnění, povinnost použít blankosměnku. Ani u platebních blankosměnek tedy nemá směnečné vyplňovací právo charakter povinnosti. Směnečné vyplňovací právo je tedy právem utvářecím (kreačním oprávněním, kompetenčním oprávněním).

Jak již bylo uvedeno výše, systematické zpracování utvářecích práv v českém právním prostředí zatím chybí. Zařazení směnečného vyplňovacího práva mezi práva utvářecí tak s ohledem na různé vlastnosti utvářecích práv nedává odpovědi na otázky s vyplňovacím právem související. Tak např. některá utvářecí práva se v českém právním prostředí promlčují, některá ne. Zařazení směnečného vyplňovacího práva mezi utvářecí oprávnění je tedy pouze vyjasněním jeho postavení v systému práv, s ohledem na chybějící obecnou charakteristiku těchto utvářecích práv však jen s dílčími dopady na jeho vlastnosti.

\section{Závěr}

I přes shodné názory na základní charakteristické rysy směnečného vyplňovacího práva se názory na jeho povahu liší. Příspěvek si proto kladl za cíl zařadit směnečné vyplňovací právo do systému práv a objasnit jeho podstatu.

Směnečné vyplňovací právo nepůsobí jako absolutní práva vůči neurčitému počtu subjektů, ale mezi tím, kdo jej vykonává, tedy nabyvatelem blankosměnky, a jejím výstavcem; je tedy právem relativním. Vyplňovací právo není právem věcným, není vázáno na předmět právního vztahu, ale na jeho účastníky, lze je proto zařadit mezi práva závazková. Dále je lze zařadit mezi majetková práva - nelze je zařadit mezi práva osobní, nebot' není spojeno s osobností člověka ani s jinými stránkami této osobnosti. Směnečné vyplňovací právo lze tedy charakterizovat jako relativní závazkové majetkové právo.

Směnečné vyplňovací právo není svou povahou plnou mocí, zmocněním, nebot’ nabyvatel blankosměnky vykonává vlastní právo, nikoli právo výstavce, k jehož výkonu byl zmocněn. Směnečné vyplňovací právo nelze označit ani jako podmínku ve smyslu \528 OZ; pokud se hovoří o podmíněném směnečném závazku, je tak možné činit pouze v obecném významu slova podmínka, tedy že vznik směnečného závazku

65 BÁNYAIOVÁ, Alena. \1909 (Směnka jako prostředek placenî). In: ŠVESTKA, Jiří a kol. Občanskéy zákeonik: Komentár, Svazek V (S 1721-2520). Praha: Wolters Kluwer, 2014, s. 375. ISBN 978-80-7478-638-9. 
je závislý na doplnění blankosměnky. Směnečné vyplňovací právo je utvářecím právem. Jeho podstatou je oprávnění $\mathrm{k}$ doplnění blankosměnky a tedy $\mathrm{k}$ její přeměně na úplnou směnku. Nejedná se ani o pohledávku - tedy právo na plnění, ani o dluh, tedy povinnost plnit. Jedná se o právo bezprostředně působit na právní poměr a tím způsobit jeho vznik. Stejně jako pohledávky a dluhy tvoří obsah závazkového vztahu.

Odpověd’ na otázky o jeho promlčitelnosti nebo způsobu převodu však zařazení věnovacího práva mezi utvářecí práva neposkytuje. V českém právním prostředí chybí systematické zpracování utvářecích práv, v jednotlivých případech se tyto otázky posuzují odlišně. 